\title{
The Representative Speech Model of Gay Coming Out: Pragmatic Study
}

\author{
Wini Tarmini ${ }^{1}$, Novi Andayani Praptiningsih ${ }^{2}$, Rahmiwati Marsinun ${ }^{3}$ \\ ${ }^{1}$ Indonesian Language Education Study Program, Postgraduate School \\ Universitas Muhammadiyah Prof. DR. HAMKA \\ ${ }^{2}$ Communication Department/Social and Political Science Faculty \\ Universitas Muhammadiyah Prof. DR. HAMKA \\ ${ }^{3}$ Counseling Guidance Department /Education Science Faculty \\ Universitas Muhammadiyah Prof. DR. HAMKA
}

winitarmini@uhamka.ac.id

\begin{abstract}
This research is entitled Representative Speech Model of Gay Coming Out: Pragmatic Study. The research method used a qualitative descriptive research design. Data collection was carried out by recording data with in-depth interviews, FGDs, and observations. The data analysis technique used the interactive model of Miles Huberman's analysis. The results of the study were representative speech models of gay coming out shows a speech act that binds the speaker to the truth he says is marked by the speech of stating, recognizing, reporting, giving testimony, mentioning, speculating. From 60 speech data, it was found that representative speeches stated as many as 25 , speeches of acknowledging as many as 11 , speeches of reporting as many as 8 , speeches of gaving testimony as many as 11 , speeches of mentioning as many as 1 , and speeches of speculating were 4. Representative speech of stating is speech that dominates the speech of gay coming out. From a psychological point of view language behavior of gay coming out expresses more their speeches according to what they feel. The events that occur are marked by a context which indicates the place and time of the incident and a lingual marker in the form of the first person pronoun, namely I and, gue, the indicative pronoun "That, and lingual markers for example, suppose, what is the name.
\end{abstract}

Keywords: Representative Speech, Gay "Coming Out".

\section{INTRODUCTION}

The existence of gays in several European countries and parts of America has begun to be "recognized" by the existence of laws that allow same-sex marriage. The United States is the 23rd country to legalize same-sex marriage on June 26, 2015,[1] . But in reality, from the past until now, gays have not or have never received full recognition from the community. Likewise, in society in Indonesia, the existence of gays has not and cannot be accepted. Such conditions make gay people careful to open themselves up in society.
From the results of research conducted by Praptiningsih[1], it was stated that there are gay people in Jakarta who have fully stated their identity as gay or in other terms called gay "coming out". However, there are also gays who have not been fully out. They will make a disclaimer by trying to deny and hide their identity as gay. Only in the gay community, both gays who have or have not been coming out, are both open to self-promotion as a technique for presenting themselves.

Gays of coming out who are in a gay community in Jakarta have their own uniqueness. They have characteristics that include values and norms based on 
the mindset and communication patterns, including attitudes, behaviors and lifestyles that differ significantly from the general population. The communication symbols they use in their interactions provide their own characteristics that can represent the gay community.

How the gays of coming out communicate to state that they are gay related to speech acts that bind the speakers to the truth of what they say. This type of speech act is called a representative or assertive speech act. Representative or Assertive speech acts include speech of stating, demanding, recognizing, showing, reporting, giving testimony, mentioning, speculating[2]. To find out how the speech of gay people coming out need a more in-depth study. In line with this, this research is entitled "THE REPRESNTATIVE SPEECH MODEL OF GAY COMING OUT: PRAGMATIC STUDY

The formulation of the problem in this study is how are representative speeches of gay coming out in expressing the meaning of the speech?

For this reason, the specific purpose of this study is to provide information and an overview of representative speech models of gay coming out.

The stages of the method in this research consisted of (i) field research to obtain primary data which was carried out through direct data recording from in-depth interviews with gay coming out, FGD, and field observations and (ii) library research to obtain secondary data conducted through books, journals, and related research results. The data analysis technique used the interactive analysis model of Miles Huberman.

The urgency of research is (1) strengthening integrated superior research as an activity of Catur Dharma higher education which is able to increase value for universities and academics; (2) the results of this study become an integral part of the learning process; (3) this research report can be an attraction for stakeholders to carry out research collaboration with UHAMKA; (5) the research output can improve the university image in the form of copyright.

\section{METHOD}

This study used a qualitative descriptive research design which aims to describe the existing phenomena. Djajasudarma [3] argues that the descriptive research method aims to provide a systematic, factual, and accurate description of the data, properties and relationships of the phenomena being studied according to the nature of the data itself. In qualitative research, humans are placed as the main subject in a social event.

The method stages in this study consisted of (i) field research to obtain primary data which was carried out through direct data recording from in-depth interviews, FGDs, and field observations. (ii) Library research to obtain secondary data is carried out through books, journals, and related research results. In-depth interviews can give informants complete freedom in expressing their opinions. Furthermore, Focus Group Discussion (FGD) is a data collection technique in qualitative research to obtain data from a group based on the results of a discussion focused on a particular problem. This technique is used to avoid the wrong meaning of a researcher because of the encouragement of the researcher's subjectivity. And field observations are carried out by researchers to add to the experience directly and allow seeing and recording events in real circumstances.

The data analysis technique in this study uses qualitative data analysis techniques developed by Miles and Hubberman, namely interactive model analysis. This analysis model focuses on three components, namely data reduction, presenting data, and drawing conclusions / verifications that involve the researcher's interpretation process.

\section{RESULTS AND DISCUSSION}

The study of the representative of gay coming out speech model describes the language behavior of the representative gay coming out speech that binds to the truth of what it says. The data source of this research is utterances of gay coming out in a gay community in Jakarta. The results showed that from 60 speech data, there were 25 speeches of representative stating, 11 speeches of recognizing, 8 of reporting, 11 giving testimonies, 1 mentioning, and 4 speculating speeches of gay coming out. The percentage distribution of representative gay coming out speech data is as follows. 


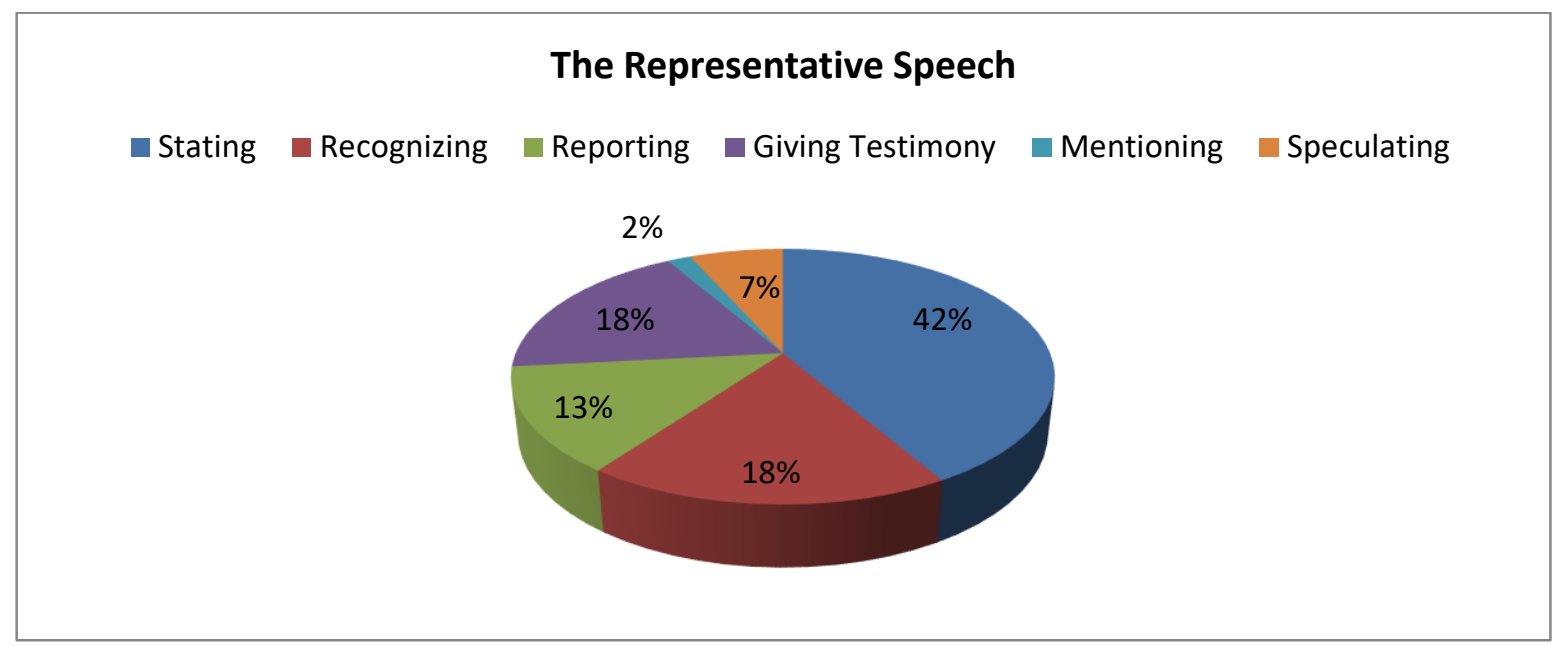

The percentage description of the representative speech data of gay coming out is as follows, the speech of representative of stating is 25 or $42 \%, 11$ or $18 \%$ of the speech of reporting, or the equivalent of $13 \%, 11$ or 13 equivalent to $18 \%$, speech of mentioning amounted to 1 or the equivalent of $2 \%$, and speech of speculating amounted to 4 or the equivalent of $7 \%$. The results of the research on the representative speech model as a whole, from a psychological point of view, show that the language behavior of gay coming out expresses more statements according to what they feel, Determination of the representative speech model of gay coming out is determined based on the context of the incident which is marked by the existence of an event that shows the place and time, and is marked by a lingual marker in the form of the first person pronoun I, gue.

Table 1. The Representative Speech with the lingual marker and the context of events

\begin{tabular}{|c|c|c|c|}
\hline No & Representative Speech & Context of Events & $\begin{array}{l}\text { Grammatical marker } \\
\text { /Lingual }\end{array}$ \\
\hline 1 & Stating & $\begin{array}{l}\text { Providing an informative } \\
\text { explanation relating to what they } \\
\text { feel and experience }\end{array}$ & $\begin{array}{l}\text { Grammatical marker of } \\
\text { declarative sentence }\end{array}$ \\
\hline 2 & Recognizing & $\begin{array}{l}\text { gave a statement pointing at } \\
\text { theirselves }\end{array}$ & $\begin{array}{l}\text { The lingual marker of } \\
\text { first-person pronoun, I }\end{array}$ \\
\hline 3 & Reporting & $\begin{array}{l}\text { Marked by the context in which } \\
\text { the activities are carried out }\end{array}$ & $\begin{array}{l}\text { Grammatical markers: } \\
\text { description of the place }\end{array}$ \\
\hline 4 & Giving Testimony & $\begin{array}{l}\text { characterized by contexts } \\
\text { involving time based events }\end{array}$ & $\begin{array}{l}\text { Grammatical markers: } \\
\text { description of time } \\
\text { Lingual marker } \\
\text { Since Elementary School } \\
\text { Junior high and Junior } \\
\text { High school time }\end{array}$ \\
\hline 5 & Mentioning & $\begin{array}{l}\text { Marked by the existence of a } \\
\text { sequence of objects }\end{array}$ & $\begin{array}{l}\text { Lingual marker } \\
\text { Comic book }\end{array}$ \\
\hline 6 & Speculating & $\begin{array}{l}\text { Statements that are still uncertain } \\
\text { are marked }\end{array}$ & $\begin{array}{l}\text { The grammatical marker is } \\
\text { a question sentence } \\
\text { Lingual markers, for } \\
\text { example, suppose }\end{array}$ \\
\hline
\end{tabular}

Pragmatics is a study of a speaker's meaning which is adjusted to the context so that what is communicated is possible to be more understood than what is said. Understanding of meaning in a pragmatic perspective is influenced by the expression of relative distance which causes speakers to consider what they say and do not say [2]. Pragmatic studies can provide benefits, namely being able to discuss the meaning intended by people according to their assumptions, intentions or goals, and the types of actions they propose when speaking [4]. 
Levinson in Tarigan [5] states that pragmatics is the study of the relationship between language and context which is the basis for a note or report on language comprehension, in other words, a study of the ability of language users to connect and align sentences and contexts appropriately. Speech acts or utterances in a pragmatic context are used according to the intent of the speech to be conveyed[6]. Speech Act Theory (SAT) represents an utterance-analysis tool for establishing a connection between grammatical forms and language functions in specific contexts.

Searle classifies speech acts into 5 types of speech. The five types are representative, directive, expressive, commissive, and declaration speech acts. Representative is a speech act that binds the speaker to the truth of what he says. This type of speech act is also known as assertive speech act. Included in this type of speech act are speeches stating, demanding, recognizing, showing, reporting, giving testimony, mentioning, and speculating.

\subsection{Representative Speech of Stating}

Representative speech model of stating in the context of events provides an informative explanation related to what is directly felt and experienced. There were 25 representative speech of stating found in the speech data.

The following are some examples of representative speeches of stating.

1. because I'm sure I'm gay. Coming out is the process of a person living with a gay sexual orientation finally being able to live as himself. Because with coming out, finally we don't get caught up in lies with other lies, so that no one party gets hurt like that. By coming out, we also learn to accept ourselves as we are.

2. I have dated three times with civil servants from the Ministry of Finance. They are from wealthy circles and have at least a $\mathrm{S} 2$ degree.

3. At least papa knows and actually papa is somewhat contradictory. Papa said if you want to live like that, you have to stand under your own feet and 'I could it now'. So, I have to 'go', that I can be without you, without deposits from my parents and since then I can be independent. So now I am completely alone and separated from my family, yes, but I still communicate with family but not often. It is rare to come without any interest, because besides being busy, I am not the typical "child of mom"

Based on sentence data, it can be argued that the five sentences can be included in the speech of the representative stating sentence because it ties the speaker to the truth of what he is saying. In the context of the three speech data events, each of them provides an informative explanation relating to what is felt and experienced by the speaker. In data there is a statement..." I'm sure I'm gay. Coming out is the process of a person living with a gay sexual orientation finally being able to live as himself. Because with coming out, we won't get caught in a lie..." Furthermore, on data there is a statement ..." I have dated three times with civil servants from the Ministry of Finance.' In data there is a statement" So, all right, I have to 'go', that I can be without you, without deposits from my parents and since then I can be independent"

For further explanation of the data, please see the data attachment for the representative speech model of stating.

\subsection{Representative Speech of recognizing}

Representative speech model of recognizing in the context of events provides an informative explanation related to what is directly felt and experienced. Representative speeches of recognizing found as many as 11 speeches contained in the data. The following are some examples of representative speech of recognizing.

1. " "And I am quite a stubborn student because I am discussing a matter from the side of another religion, not from Islam. In fact, the lecturers disagree somewhat ..."

2. "I became gay because I lived with a mother who was a single parent because of divorce and trauma because I had experiences with women cheating on me..."

3. Previously, I was close to going out and really close to one of the actors who was also gay, but it didn't happen because he had a crush on a young and famous fashion designer who was so smitten with him. I'm alone now

Based on sentence data, it can be argued that these three sentences can be included in the speech representatitf of recognition which also binds the speaker to the truth of what he is saying. In the context of the events, the three speech data each gave a statement pointing to themselves. In data there is a recognition"I'm quite a stubborn student because I ..." Furthermore, in data there is recognition " $I$ 'm gay because I live with ...." And on the data "...I was almost dating and very close...."

For further explanation of the data, see the data attachment for representative speech models of recognition. 


\subsection{Representative Speech of Reporting}

Representative speech models of reporting in the context of events provide informative explanations related to what is directly felt and experienced. Representative speech of reporting found as many as 8 speeches contained in the data, The following are some examples of representative speeches of reporting.

1. "I communicate with community members every day via WA, line, telephone, or come directly to the secretariat...."

2. "If there is an event I will definitely attend. Happy meeting them. Even though they are friends with them, I have never been able to fall in love with fellow members of the community. The problem is already like siblings, friends of the same heart"

3. "The Arus Pelangi event is really ok. How broke the show. Funny and informative. In fact, we don't feel like we're being educated, especially for those who haven't come out yet, the reinforcement is extraordinarily excited. Not being boring, we feel at home for a long time at this event."

In the context of the event, the three speech data, respectively, report related to conditions or circumstances / place. In data “...every day I do it via $W A$, line, telephone, or come directly to the secretariat ...." Furthermore, in data "If there is an event I will definitely attend ..." In data "The Arus Pelangi event is really ok ... in this event."

For further data explanation, it can be seen in the data attachment for representative speech model of reporting.

\subsection{Representative Speeches of Giving Testimony}

Representative speech models of giving testimony in the context of giving testimony events are characterized by contexts that involve past events. There are 11 representative speeches of giving testimony found in the data. The following are examples of representative speeches of giving testimony.

1. "When I was in junior high and high school, I had a date.... The girl keeps changing like that, so it's only been 2 months with this guy, then suddenly he's close to that guy again. Labeled a playboy at that time. But actually since fifth grade elementary school I started having a crush on guys too, fantasies like that."

2. "In grade 3 in high school I was honest with my mom that I was gay, Mom accepted it, but she said that I should be responsible for my life choices."

3. "Since junior high school I was often bullied, said to be a sex criminal, and even now, I still get bullied by my workmates just because I often wear a totte-bag. That's why I often resigned and moved jobs several times."

In the context of the three narrative data, each of them gave testimony which was marked by a context involving events based on the past as evidence of the incident. This can be seen in the data "When I was in junior high and high school, I was dating. The girl keeps changing like that, so it's only been 2 months with this guy, and that's all ...." In data "In grade 3 in high school I was honest with my mom that I was gay, she accepted it ..." Next up in the data "Since junior high school I was often bullied, said to be a sex criminal ...."

The lingual markers that appear are junior high and high school time, since junior high school

For further explanation of the data, please see the attachment of a representative speech model of giving testimony.

\subsection{Representative Speeches of Mentioning}

The representative speech model of mentioning in the context of the event provides an explanation that shows a thing or object and is marked with a lingual marker of indicator word that. Representative speech of mentioning is only found in 1 speech contained in the data.

"So mom's books have lots of books, so it's an opportunity. There are also lots of comics, but it's very rare and not typical that follow comics from series 1-3, but I read a lot of my mother's books.

\subsection{Representative Speeches of Speculating}

Representative speech model of speculating in the event context provides a statement that is characterized by the context of the event that is still uncertain. Representative speech of speculating found as many as 4 speeches contained in the data. The following are examples of representative speeches of speculating.

1. "Now, I have no desire to... what is it called? For example close to women or I myself have dreams of life ..."

2. During the Queer Film Festival in Jakarta, a threatening tone occurred against the film. 
People think that a film festival like this will encourage moral damage to the nation and make people think that gay behavior can be imitated and carried out freely in this country."

3. So he said okay if you like this, it's your choice of life, everyone has a choice of life, but learning to be responsible for what you have chosen, that's what I always hold until now.

In the context of the event, the three speech data each gave a statement that still did not show certainty. It is marked by lingual markers for example, supposes, and question markers of doubt ... what is the name?

\section{CONCLUSIONS}

Based on the results of data analysis, it can be concluded that the study of representative speech model of gay "coming out" indicates a speech act that binds the speaker to the truth of what he is saying. This is marked by speech which states, acknowledging, reporting, testifying, mentioning, and speculating. Of the 60 speech data, it was found that representative speeches amounted to 25 , acknowledging speeches totaled 11 , reporting speeches were 8 , and testifying speeches totaled 11, stating speeches numbered 1 , and speculating speeches totaled 4 . The speech states that it is a speech that dominates speech of gay coming out. From a psychological point of view, the results of the study show that the language behavior of gay coming out expresses more statements according to what they feel. The determination of the representative speech model of gay coming out is based on the context of the incident which is marked by the occurrence of an event that shows the place and time of the incident and a lingual marker in the form of the first person pronoun of I, me, the pointer pronoun, the lingual marker for example, suppose, what is the name.

\section{REFERENCES}

[1] N. Praptiningsih and dkk, "Implementaion of Business Communication in Gay Dramaturgy," $J$. Commun. Perspect. J. Perspekt. Komun., vol. 2, no. 2, 2018.

[2] W. Tarmini and I. Safii, "Kesantunan Berbahasa Civitas Academiva UHAMKA," Kaji. Sosiopragmatik, vol. 01, no. 1, pp. 77-91, 2018.

[3] T. Fatimah, Djajasudarma. Wacana dan Pragmatik. Bandung: Refika Aditama.2012.

[4] C. Maiz, Expressive Speech Act in Educational El uso de actos expresivos en chat educacionales, vol. 5, no. 2. 2017.

[5] T. Tarigan, Pengajaran Pragmatik. Bandung: Angkasa, 2009.

[6] S. Studies, "Pragmatic Forces in The Speech Acts of EFL Speakers At Kampung Inggris," Indones. Muhamd Mukhroji 1 Joko Nurkamto 2 HD Edi Subroto3 Sri Samiati Tarjana4, vol. 10, no. 1, pp. 38-60, 2019. 